\title{
The importance of small artificial water bodies as sources of methane emissions in Queensland, Australia
}

\author{
Alistair Grinham ${ }^{1}$, Simon Albert ${ }^{1}$, Nathaniel Deering ${ }^{1}$, Matthew Dunbabin ${ }^{2}$, David Bastviken ${ }^{3}$, Bradford Sherman $^{4}$, \\ Catherine E. Lovelock ${ }^{5}$, and Christopher D. Evans ${ }^{6}$ \\ ${ }^{1}$ School of Civil Engineering, The University of Queensland, Brisbane, 4072, Australia \\ ${ }^{2}$ Queensland University of Technology, Institute for Future Environments, Brisbane, QLD, Australia \\ ${ }^{3}$ Department of Thematic Studies-Water and Environmental Studies, Linköping University, \\ Linköping, 58183, Sweden \\ ${ }^{4}$ CSIRO Land and Water, Canberra, 2601, Australia \\ ${ }^{5}$ School of Biological Sciences, The University of Queensland, Brisbane, 4072, Australia \\ ${ }^{6}$ Centre for Ecology and Hydrology, Environment Centre Wales, Bangor, LL57 2UW, UK
}

Correspondence: Alistair Grinham (a.grinham@uq.edu.au)

Received: 29 May 2018 - Discussion started: 2 July 2018

Accepted: 27 September 2018 - Published: 15 October 2018

\begin{abstract}
Emissions from flooded land represent a direct source of anthropogenic greenhouse gas (GHG) emissions. Methane emissions from large, artificial water bodies have previously been considered, with numerous studies assessing emission rates and relatively simple procedures available to determine their surface area and generate upscaled emissions estimates. In contrast, the role of small artificial water bodies (ponds) is very poorly quantified, and estimation of emissions is constrained both by a lack of data on their spatial extent and a scarcity of direct flux measurements. In this study, we quantified the total surface area of water bodies $<10^{5} \mathrm{~m}^{2}$ across Queensland, Australia, and emission rates from a variety of water body types and size classes. We found that the omission of small ponds from current official land use data has led to an underestimate of total flooded land area by $24 \%$, of small artificial water body surface area by $57 \%$ and of the total number of artificial water bodies by 1 order of magnitude. All studied ponds were significant hotspots of methane production, dominated by ebullition (bubble) emissions. Two scaling approaches were developed with one based on pond primary use (stock watering, irrigation and urban lakes) and the other using size class. Both approaches indicated that ponds in Queensland alone emit over $1.6 \mathrm{Mt} \mathrm{CO}_{2}$ eq. $\mathrm{yr}^{-1}$, equivalent to $10 \%$ of the state's entire land use, land use change and forestry sector emissions. With limited data from other regions suggesting sim-
\end{abstract}

ilarly large numbers of ponds, high emissions per unit area and under-reporting of spatial extent, we conclude that small artificial water bodies may be a globally important missing source of anthropogenic greenhouse gas emissions.

\section{Introduction}

Over the last 20 years, greenhouse gas (GHG) emissions studies from large, artificial water bodies such as water supplies or hydroelectric reservoirs have clearly demonstrated these are major emissions sources. Whilst carbon dioxide $\left(\mathrm{CO}_{2}\right)$, nitrous oxide $\left(\mathrm{N}_{2} \mathrm{O}\right)$ and methane $\left(\mathrm{CH}_{4}\right)$ can all be emitted, the most recent global synthesis of artificial water body emissions demonstrated that, when converted to $\mathrm{CO}_{2}$ equivalents, $\mathrm{CH}_{4}$ accounted for $80 \%$ of fluxes (Deemer et al., 2016). Increasingly sophisticated reviews have explored the magnitude of the artificial water body contribution to regional and global $\mathrm{CH}_{4}$ budgets (St. Louis et al., 2000; Bastviken et al., 2011; Deemer et al., 2016). Much of the focus in reducing the uncertainty from this anthropogenic greenhouse gas source has focussed on the spatial and temporal variability in total emission rates and, in particular, the relative contribution of $\mathrm{CH}_{4}$ bubbling (ebullition) directly from the sediment (Bastviken et al., 2011). To enable large-scale emissions estimates from larger, artificial water bodies, re- 
lationships between eutrophication status and sediment temperature (Aben et al., 2017; Harrison et al., 2017) have been developed to predict both diffusive and ebullitive emission rates. However, in regional or global scaling of emissions it is important to examine the emission rates of all types and sizes of artificial water bodies (Panneer Selvam et al., 2014). Furthermore the surface area of small water bodies can be particularly difficult to quantify in national and global datasets due to their small size and large number (Chumchal et al., 2016). In addition, the peripheral areas of small water bodies regularly experience periods of inundation and no inundation as water levels change due to their relatively shallow nature and high water use rates. The changes in their inundation status may influence emission rates as has been observed for natural ponds (Boon et al., 1997). Given that there are estimated to be 16 million artificial water bodies with a surface area less than $0.1 \mathrm{~km}^{2}$ (Lehner et al., 2011), understanding the rates and variability in emissions from these flooded lands will be an important refinement to global $\mathrm{CH}_{4}$ budgets.

The increasing urbanisation of society as well as the expansion of agriculture and commercial mining activities has resulted in a proliferation of small artificial water bodies in many parts of the globe (Renwick et al., 2005; Downing et al., 2006; Pekel et al., 2016). This is well illustrated by the example from the United States where artificial small water bodies increased from an estimated 20000 in 1934 (Swingle, 1970) to over 9 million in 2005 (Renwick et al., 2005). These water bodies provide valuable services and are required to irrigate crops, provide water for farm stock, manage storm water, offer visual amenity and recreational activities, and supply water for industrial processes (Fairchild et al., 2013). Small water bodies are often avian biodiversity hotspots, for example hosting an estimated 12 million water birds in a single catchment area in the Murray-Darling river system, Australia (Hamilton et al., 2017).

The creation of small artificial water bodies also represents a transformation of the landscape, referred to in the Intergovernmental Panel on Climate Change land use emission accounting procedures as "Flooded Lands" (IPCC, 2006). Where the creation of small water bodies leads to new greenhouse gas emissions, these emissions are considered anthropogenic in origin according to IPCC guidelines (IPCC, 2006) and should therefore be included in Flooded Lands emissions inventories (Panneer Selvam et al., 2014). In addition, quantifying methane emission from ponds will improve our understanding of their role in the global carbon cycle. The potential of ponds as major organic carbon sinks has been established (Downing, 2010), although the stability and permanence of organic carbon trapped within ponds is critical to determining the magnitude of this sink. Loss pathways include active de-siltation (Verstraeten and Poesen, 2000), breaching of fully silted dams (Boardman and Foster, 2011) and methane emissions.

To date, the relatively few regional studies on small, artificial water bodies (hereafter "ponds") have focussed on water and sediment dynamics rather than GHG emissions (Downing et al., 2008; Callow and Smettem, 2009; Verstraeten and Prosser, 2008; Habets et al., 2014). Studies of GHG emissions from ponds have been limited (Downing, 2010; Deemer et al., 2016) but are in agreement with assessments of larger water bodies where $\mathrm{CH}_{4}$ is the dominant GHG relative to $\mathrm{N}_{2} \mathrm{O}$ and $\mathrm{CO}_{2}$ (Merbach et al., 1996; Natchimuthu et al., 2014). The only regional-scale study to date was undertaken in India by Panneer Selvam et al. (2014). In order to quantify the role of artificial ponds in the global $\mathrm{CH}_{4}$ cycle, as well as their role as a source of anthropogenic emissions, it is necessary to obtain both estimates of $\mathrm{CH}_{4}$ fluxes from a broader range of sites and also to estimate the surface area contributing to emissions. An important part of the value of building a dataset of $\mathrm{CH}_{4}$ flux estimates from a broad range of sites is determining factors that account for spatial and temporal variability in the flux. Surface area estimates can be problematic given the range of water types (small urban lakes to large irrigation ponds) that fall within the definition of "ponds", their frequently high temporal variation in surface area, the sheer number of such water bodies and their ongoing increase in number over time.

Here, we present the first regional-scale assessment of $\mathrm{CH}_{4}$ emissions from ponds in the Southern Hemisphere and, following the assessment of Panneer Selvam et al. (2014), only the second regional assessment globally. The assessment was undertaken in the 1.85 million $\mathrm{km}^{2}$ state of Queensland, Australia. Queensland provides an effective test case for the estimation of $\mathrm{CH}_{4}$ emissions from ponds because (i) it incorporates a high degree of spatial variability in land use and climate, from desert to humid tropics; and (ii) the irregular rainfall patterns and wide spatial coverage of aerial imagery result in a large number of artificial ponds, which are relatively easy to quantify. $\mathrm{CH}_{4}$ emissions from these ponds can be considered anthropogenic in origin, because past studies of rainforest and agricultural soils in the region have clearly shown these terrestrial landscapes were weak $\mathrm{CH}_{4}$ sinks (ranging from -0.02 to $-5 \mathrm{mg} \mathrm{CH}_{4} \mathrm{~m}^{-2} \mathrm{~d}^{-1}$ ) prior to inundation (Allen et al., 2009; Scheer et al., 2011; Rowlings et al., 2012).

The principal objective of this study was to establish the GHG status of ponds in Queensland, Australia. Given the paucity of GHG data from ponds, this study has focussed on empirical assessments of $\mathrm{CH}_{4}$ emissions from a range of pond types rather than detailed assessments of drivers of these emissions. Our assessment is comprised of four components:

1. Quantify the area of ponds, relative to regional assessments of larger artificial water bodies.

2. Quantify $\mathrm{CH}_{4}$ emission rates for a wide spectrum of pond types.

3. Determine variability in their surface area and emission rates. 
4. Determine the influence of inundation level on emission rates.

When integrated together, these components provide a robust regional assessment of anthropogenic $\mathrm{CH}_{4}$ emissions for ponds in Queensland, Australia.

\section{Methodology}

\subsection{Study area description}

Queensland, the second largest state in Australia, covers a surface area of 1.85 million $\mathrm{km}^{2}$ and has a population of 4.75 million people. Land use across the state is dominated by agriculture with over $80 \%$ of the total surface area utilised for grazing cattle or irrigated cropping (Fig. 2a; QLUMP, 2018). The Queensland agriculture sector contributes more than AUD 13 billion per year to the state economy and includes 15 million cattle and sheep as well as $4526 \mathrm{~km}^{2}$ of land under irrigation (ABS, 2018). The climate is subtropical or tropical with mean annual temperatures ranging from $27.5^{\circ} \mathrm{C}$ in the state's north to $15.8^{\circ} \mathrm{C}$ in the southern interior. There are large gradients in rainfall across the state ranging from a mean annual rainfall of over $3000 \mathrm{~mm}$ in the coastal north-east to less than $100 \mathrm{~mm}$ in the arid western regions (Fig. 2b). Rainfall has a distinct annual pattern with up to $80 \%$ falling during the summer months from November to April and is subject to decadal drought and flood cycles (Klingaman et al., 2013). The economic importance of agriculture coupled with the need to provide a year-round water supply for these activities and the lack of predictable rainfall has resulted in the proliferation of artificial water bodies across the state (Fig. A1 in the Appendix). However, the number and surface area of ponds in Queensland is relatively unknown as there is no legal requirement to refer ponds to the state registry due to their small size. Under current state law only dam walls in excess of $10 \mathrm{~m}$ and volumes above $750 \mathrm{ML}$ (megalitres) are referable (DEWS, 2017) and the maximum reported volume for ponds in Queensland is 3 times less than the referable volume ( $<250 \mathrm{ML})$ (SKM, 2012). This study has assumed ponds are less than $100000 \mathrm{~m}^{2}$ as this is recognised globally as the major area of uncertainty in surface area assessments (Lehner and Döll, 2004; Downing, 2010) and has been identified as a threshold in global lake inventories (Downing et al., 2006; Verpoorter et al., 2014).

\subsection{Relative surface area of ponds across the region}

To determine the number and relative surface area of ponds across Queensland, three state government GIS databases of artificial water bodies were utilised. However, these databases required additional processing to extract comparable pond data as there were inconsistencies in the format and nomenclature of feature types. The primary database used was the most recent official assessment of land use from
March 2018 (QLUMP, 2018), and within the primary land use classification of "Water" there is a secondary category of artificial "Reservoirs/dam" divided further into "Reservoirs, Water storage and Evaporation basin". The individual water body surface area is provided and all ponds $\left(<10^{5} \mathrm{~m}^{2}\right)$ were extracted from the database. Evaporation basins were excluded, as these are commonly used for salt extraction. These ponds were then compared against two state government databases from a high-resolution assessment of artificial water bodies across the state published in 2014 and 2015. Both databases are derived from aerial $(10$ to $60 \mathrm{~cm}$ orthophotography) and satellite ( 0.5 to $2.5 \mathrm{~m}$ resolution) imagery captured between 2010 and 2014. One database contains water bodies greater than $625 \mathrm{~m}^{2}$ at full supply (Reservoirs - Queensland; http://qldspatial.information.qld.gov.au/ catalogue/, last access: 28 November 2017) and for water bodies less than $625 \mathrm{~m}^{2}$ a second database was used (Water Storage Points - Queensland; http://qldspatial.information. qld.gov.au/catalogue/, last access: 28 November 2017).

Water bodies larger than $625 \mathrm{~m}^{2}$ contained individual polygons where water body surface area was provided and all water bodies less than $10^{5} \mathrm{~m}^{2}$ were extracted from the database. The database of water bodies smaller than $625 \mathrm{~m}^{2}$ contained point data providing only the location of water bodies and no information on their dimensions (Fig. A1b, c). To estimate the surface area of these systems, 100 water bodies were randomly selected using the Subset Features tool in the Geostatistical Analyst toolbox in ArcGIS (Version 10.3, ESRI Inc., Redlands, California, USA). The surface area of selected water bodies was then quantified using high-resolution aerial imagery (Nearmap; https://www. nearmap.com.au/, last access: 15 May 2018). Typical pixel resolution of $7 \mathrm{~cm}$ greatly improves edge detection of ponds as it can be very challenging to separate the water edge from riparian vegetation stands with coarser-scale data. Pond edges were mapped following the methodology of Albert et al. (2016) where imagery was georeferenced and the water edge was manually traced to create individual polygons for each pond. The mean surface area of all 100 polygons was then assumed to approximate the surface area of all individual ponds within this database and the total surface area was calculated by multiplying this mean surface area by the total number of ponds.

To ensure only one water body was reported from each location, all databases were first screened to remove repeated detections of water bodies. All remaining water bodies were then summed together to calculate the total surface area of ponds and this was compared to larger reservoirs to determine their relative surface area. To undertake regional scaling of pond emissions, individual ponds were sorted using two different size class classifications. Firstly, we categorised sites into the three smallest size classes $\left(10^{2}\right.$ to $10^{3} ; 10^{3}$ to $10^{4}$; and $10^{4}$ to $10^{5} \mathrm{~m}^{2}$ ) in the Global Reservoir and Dam (GRanD) assessment (Lehner et al., 2011). Secondly, we divided sites into water bodies less than $3500 \mathrm{~m}^{2}$ (primarily 
(a)

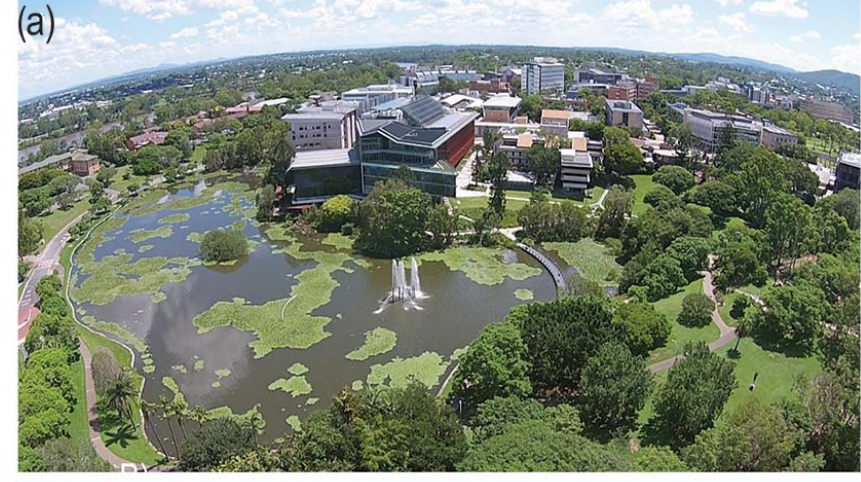

(b)

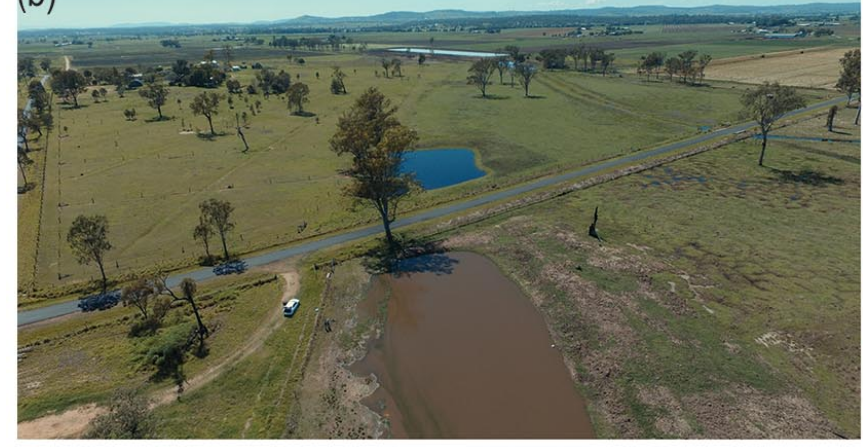

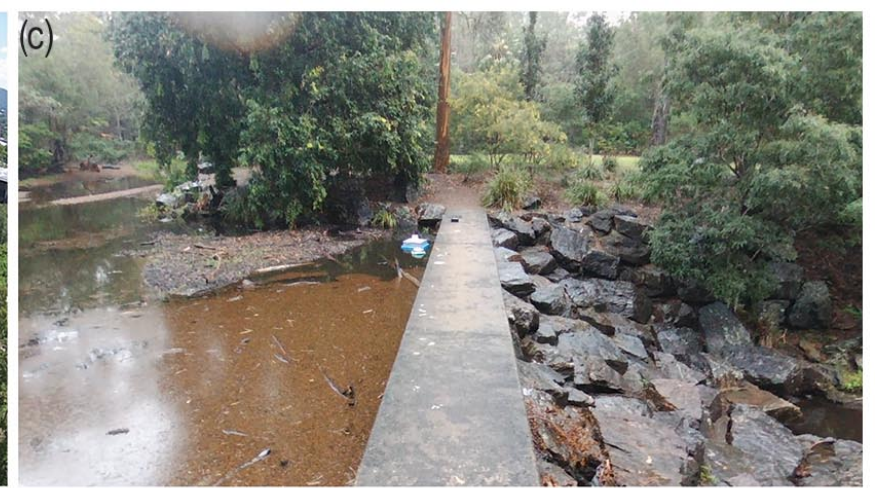

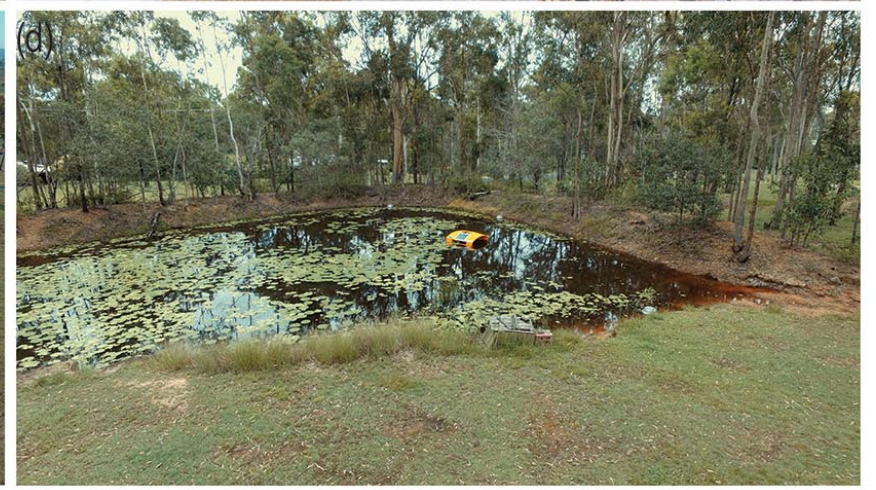

Figure 1. Oblique drone images showing examples of ponds where $\mathrm{CH}_{4}$ emissions were monitored during this study: (a) urban lake (St Lucia 1); (b) stock dams in foreground (including Gatton 4), irrigation dam in background; (c) small weir showing high organic loading upstream of wall (Mt Coot-tha); (d) rural residential dam (Greenbank).

stock dams) and larger water bodies (primarily irrigation dams and urban lakes), following the findings of Lowe et al. (2005) and SKM (2012).

\section{3 $\mathrm{CH}_{4}$ emissions from broad spectrum of pond types}

To quantify the range of emission rates from ponds, a monitoring program was undertaken from August to December 2017 across a wide spectrum of ponds including: farm dams (irrigation and stock watering), urban lakes, small weir systems (i.e. small dams leading to widening and slowing of river flows) and rural residential water supplies (Fig. 1). Stock dams, irrigation dams and urban lakes account for the vast majority of ponds across Queensland and ponds within each category were selected to represent the regional size class distribution (Fig. A2). The majority of sites were located in coastal catchments in south-east Queensland, Australia, as well as one urban lake and three stock dams in central Queensland (Fig. 2c).

There are a number of commonly used methods to assess methane emissions from water bodies depending on the pathway of interest. For the diffusive emission pathway, rates may be modelled using the thin boundary methods or directly measured using manual or automatic floating chambers (St. Louis et al., 2000). For ebullition pathways, rates can be directly measured using acoustic surveys or funnel traps (DelSontro et al., 2011). Thin boundary layer models cannot be used to quantify the ebullition pathway and acoustic surveys or funnel traps cannot be used effectively in ponds as the water depth is often too shallow $(<1 \mathrm{~m})$. We chose to use floating chambers to capture both ebullition and diffusive fluxes. $\mathrm{CH}_{4}$ emission rates were measured by deploying between 3 and 16 floating chambers per water body, covering both peripheral and central zones (Fig. A3). Chamber design followed the recommendations of Bastviken et al. (2015), as these lightweight chambers (diameter $40 \mathrm{~cm}, 12 \mathrm{~L}$ headspace volume and $0.7 \mathrm{~kg}$ total weight) were ideally suited to deployment in ponds where both site access and on-water deployments can be challenging (Fig. A4). The floating chambers used were designed to yield negligible bias on the gas exchange and compare well with non-invasive approaches (Cole et al., 2010; Gålfalk et al., 2013; Lorke et al., 2015).

Where possible, $24 \mathrm{~h}$ measurements were undertaken; however, in three water bodies this was not possible (Appendix Table A1) and here measurements lasted between 6 and $8 \mathrm{~h}$. The $24 \mathrm{~h}$ deployment time was chosen to increase the likelihood of capturing ebullition, which is episodic in nature, and of incorporating diel variability in diffusive emissions which can be up to a 2-fold bias (Bastviken et al., 2004, 2010; Natchimuthu et al., 2014). The use of longterm deployments may underestimate diffusive fluxes, which 


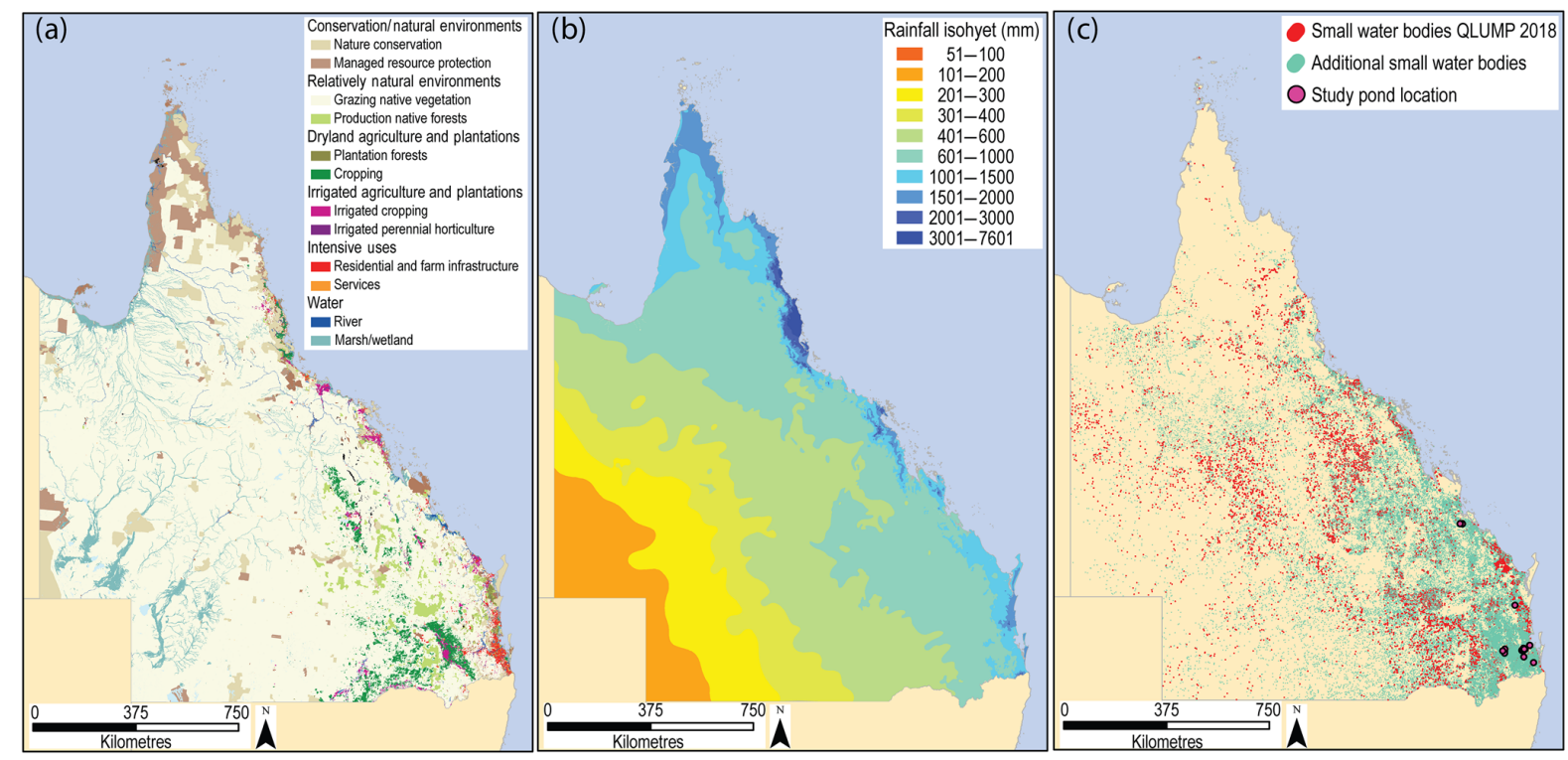

Figure 2. (a) The 2018 statewide assessment showing the relative surface area occupied by secondary land use categories (QLUMP, 2018). Note the legend shows the two largest land uses within each category. (b) Mean annual rainfall isohyets across Queensland from the 30-year period of 1961 to 1990 (http://www.bom.gov.au, last access: 13 March 2018). (c) Location of study ponds and ponds identified from the land use assessment (QLUMP, 2018) and two additional statewide databases (see text).

decrease as the chamber headspace approaches equilibrium with the water. However, in contrast to $\mathrm{CO}_{2}, \mathrm{CH}_{4}$ has a long equilibration time and it has been shown that a $24 \mathrm{~h}$ deployment of these types of flux chambers on lakes underestimate diffusive fluxes by less than $10 \%$ (Bastviken et al., 2010). An initial gas sample was collected at chamber deployment and a final chamber headspace gas sample after $24 \mathrm{~h}$ following the Exetainer method described in Sturm et al. (2015). $\mathrm{CH}_{4}$ emission rates were calculated from the change in headspace concentration over time and normalised to areal units (Grinham et al., 2011).

\subsection{Variability in surface area and emission rate}

\subsubsection{Spatial and seasonal variability across a single water body}

To gain insight into the spatial and temporal uncertainty in pond emissions we compared variability in seasonal emissions from a single site to emissions from an intensive spatial survey of multiple sites across the pond (Fig. 4). Seasonal variability in emission rates was measured at an urban lake (St Lucia 1) where monthly monitoring at a single site was undertaken across an annual cycle (January to December 2017). This pond was selected as water level remains relatively constant throughout the year and sampling would not be impacted by changes in inundation status. Emissions were monitored following the same methodology as described in the preceding section, and four or five floating chambers were deployed for each sampling event. Emission rates from this seasonal study were then compared to an intensive spatial survey of the same pond (December 2017), where 16 chambers were deployed simultaneously for a $24 \mathrm{~h}$ incubation. To better understand spatial patterns in emissions within this pond the water depth and proximity to inflow points were mapped. The bathymetric survey was conducted using a logging GPS depth sounder (Lowrance HDS7 depth sounder, Navico, Tulsa, Oklahoma, USA). Georeferenced water depth points were imported into ArcGIS and interpolated across the whole water body using the inverse distance weighting function.

\subsubsection{Variability in water surface area across all monitored ponds}

The variability in surface area of each of the 22 ponds monitored in the emissions surveys was analysed using highresolution historical imagery across all monitored water bodies. A time series of high-resolution aerial imagery over a 9-year period from 2009 to 2017 was screened for image quality and appropriate images were selected. The time series data are not consistent across the whole state; the number of discrete images for individual water bodies varied from 3 to 16. Images of individual ponds were georeferenced to a common permanent feature across all images and then the outer water edge was mapped and surface area calculated following Albert et al. (2016). The time series of surface area for individual water bodies was compared to their corresponding surface area at full supply level $\left(A_{\mathrm{FSL}}\right)$ and expressed as a percentage then grouped into three size classes based on 
the GRanD classification. This time period also captured the range of rainfall variability across the state with 2010 being the wettest year on record whilst 2013 to 2015 were consecutive drought years (Average rainfall; https://data.qld.gov.au/, last access: 10 May 2018).

\subsection{Effect of inundation status on pond emissions}

The effect of inundation status on emission rates was tested on a stock dam (Gatton 4) where measurements were undertaken on peripheral areas during periods of inundation and no inundation. This pond was selected as stock dams generally experience accelerated rates of water level change due to their relatively small size compared to other pond types (Fig. A2). In addition, the construction of this pond is typical for stock dams (a shallow pit is dug out and the soil used to construct the wall and spillway) and the surface area $\left(1893 \mathrm{~m}^{2}\right)$ closely matched the median for all farm dams $\left(1586 \mathrm{~m}^{2}\right.$; Fig. A2). Emission measurements for the inundated period followed the methodology outlined above for the water body emissions survey. Three weeks later water levels within the ponds had dropped and emission measurements were repeated at the same sites which were now exposed. For these emission measurements five chambers (90 $\mathrm{mm}$ diameter, $150 \mathrm{~mm}$ length) were carefully inserted $50 \mathrm{~mm}$ into the ground and care was taken to minimise disturbance to the soil surface. The headspace of each chamber was flushed with ambient air to remove headspace contamination due to chamber insertion, then the sampling port of each chamber was sealed. After the deployment period, a gas headspace sample was collected and $\mathrm{CH}_{4}$ concentration was analysed.

\subsection{Statistical analyses and regional scaling of emissions}

Emissions rates and surface area data were analysed using a series of one-way analyses of variance (ANOVAs) with the software program Statistica 13 (Dell Inc., 2016). Analysis of emissions rates collected during the monthly monitoring study and the inundation study used sampling month or inundation status as the categorical predictors and chamber emission rates as the continuous variable. Emission rates from individual water bodies collected during the broad survey were first pooled into four primary use categories (irrigation, stock, urban and weirs) or three different GRanD size classes and these categories were used as the categorical predictors. The primary use of each pond was provided by pond owners or managers; in the case of urban lakes that had both aesthetic and storm water functions these were classified as urban (Table A1). A total of 22 ponds were included in this survey with 4 irrigation ponds, 9 stock watering ponds, 7 urban ponds and 2 weirs. Changes in water surface area (as a percentage of $A_{\mathrm{FSL}}$ ) from individual water bodies were pooled into three GRanD size classes and these categories used as the cate- gorical predictors. Where necessary, continuous variable data were log transformed to ensure normality of distribution and homogeneity of variance (Levene's test) with post hoc tests performed using Fisher's LSD (least significant difference) test (Zar, 1984). Tests for normality were conducted using the Shapiro-Wilks test as recommended by Ruxton et al. (2015). The non-parametric Kruskal-Wallis (KW) test was used for continuous data which failed to satisfy the assumptions of normality and homogeneity of variance even after transformation. Statistical results were reported as follows: test applied (Fisher's LSD or Kruskal-Wallis test), the test statistic $(F$ or $H)$ value and associated degrees of freedom with $p$ value.

Emissions were scaled to water body size classes following two different approaches. Firstly, emissions were grouped according to their respective GRanD size class. These match the size class of water bodies used in the emissions monitoring of this study, and the GRanD database was used in the most recent global synthesis of greenhouse gas emissions from reservoirs (Deemer et al., 2016). Secondly, water bodies less than $3500 \mathrm{~m}^{2}$ in area were assumed to be primarily stock dams and larger water bodies primarily irrigation dams (Lowe et al., 2005). To extrapolate pond emission rates to regional scales, an appropriate measure of centrality should be used. Three common measures, arithmetic mean, geometric mean and median values, were calculated for each water body category and size class. To assess the most suitable measure of centrality for water body emissions, normal probability plots of raw and log-transformed emissions data were generated and tested using the ShapiroWilks test (Fig. A5). The emissions data from all replicate measurements fitted a log-normal $(p=0.081)$ but not a normal distribution $(p=0.0000)$ and, therefore, the geometric mean would provide the most appropriate measure of centrality for this data (Ott, 1994; Limpert et al., 2001). Fluxes were scaled to annual rates using the cumulative surface area of water bodies and the respective emissions rate for each size class using the geometric means. The variability in geometric mean was given by the exponential of the $95 \%$ confidence interval range of log-transformed data. Emissions for water bodies less than $3500 \mathrm{~m}^{2}$ were scaled using stock dam rates and larger water bodies ( 3500 to $10^{5} \mathrm{~m}^{2}$ ) using rates obtained from irrigation dams and urban lakes. Total fluxes from respective size classes were then combined to provide regional estimates. Annual fluxes of $\mathrm{CH}_{4}$ were converted to $\mathrm{CO}_{2}$ equivalents assuming a 100 -year global warming potential of 34 (IPCC, 2013).

\section{Results}

\subsection{Relative surface area of ponds}

The statewide land use assessment identified 13046 ponds across Queensland, occupying a total surface area of ap- 

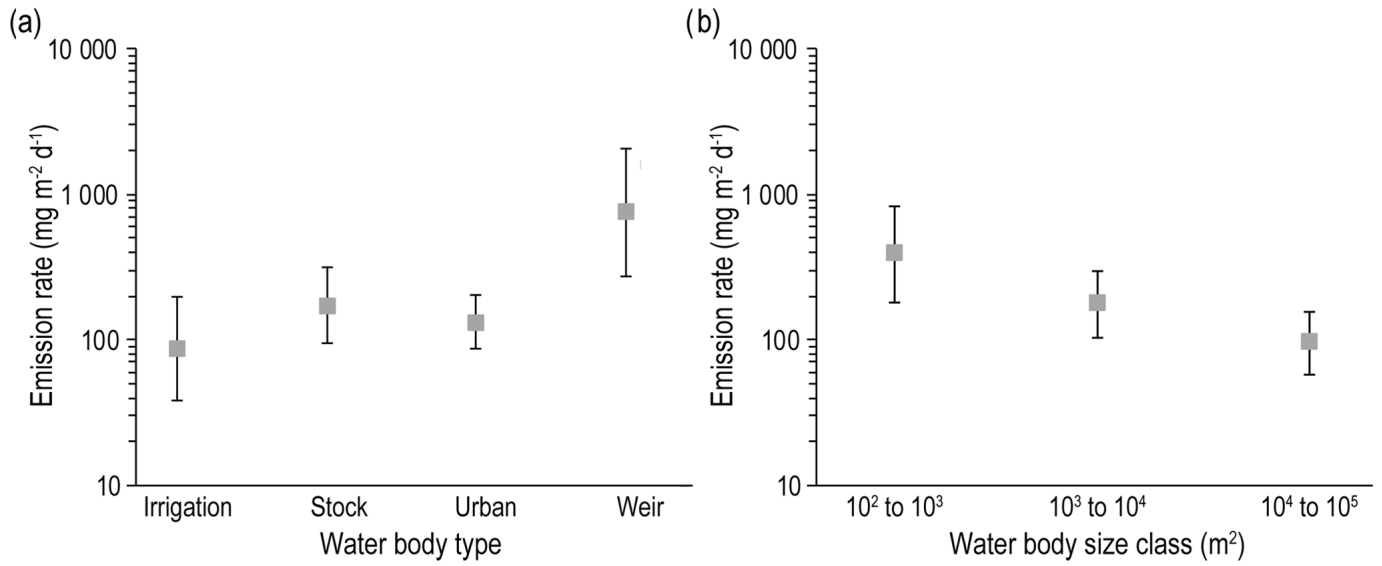

Figure 3. Mean $\mathrm{CH}_{4}$ emissions across (a) four categories of small water bodies (irrigation dams, stock dams, urban lakes and weirs) and (b) three GRanD water body size classes. Values indicate geometric mean emission rates and $95 \%$ confidence intervals $( \pm 95 \% \mathrm{CI})$.

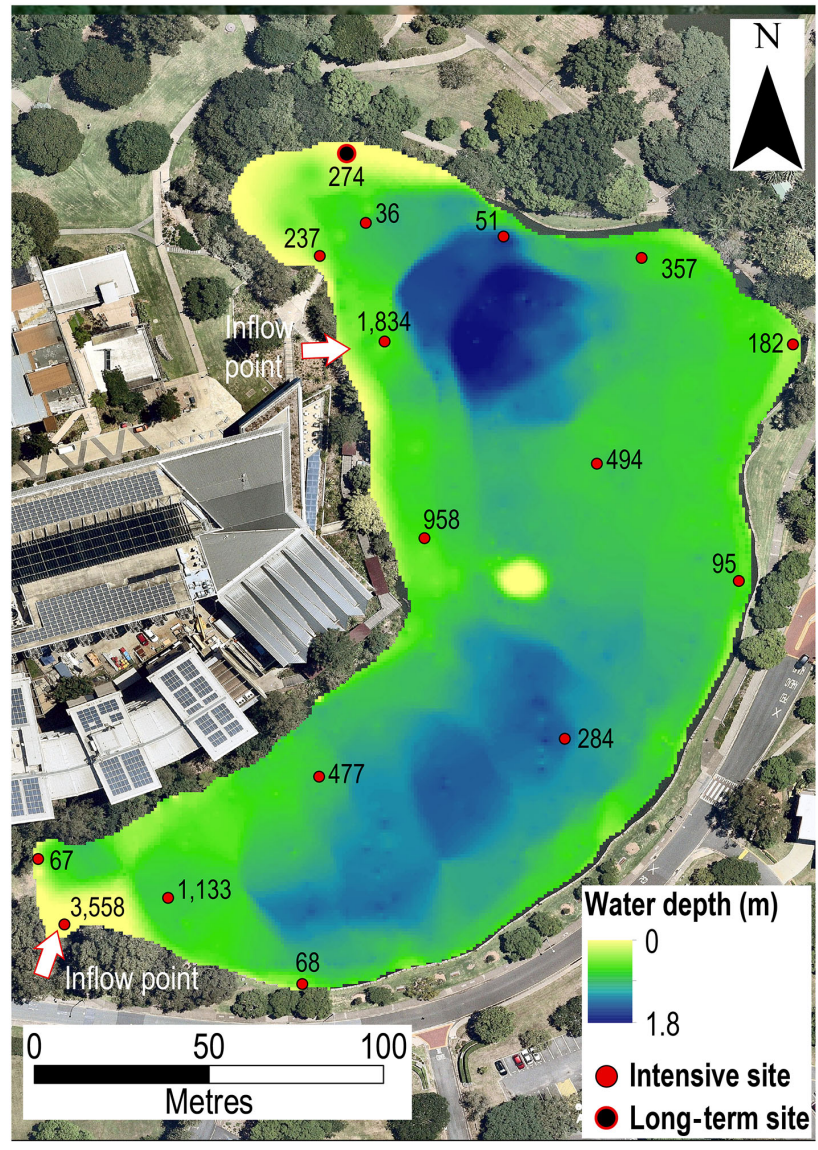

Figure 4. Sampling site location and chamber emission rates $\left(\mathrm{mg} \mathrm{m}^{-2} \mathrm{~d}^{-1}\right)$ across an urban lake (St Lucia 1) relative to water depth and proximity to storm water inflow points.

proximately $467 \mathrm{~km}^{2}$ (Fig. 2c). However, with the inclusion of the additional Reservoir and Water Storage Point datasets the number of ponds increased over 20 times to a total of 293346 , and the surface area more than doubled to $1087 \mathrm{~km}^{2}$. The official land use assessment of Queensland underestimates the surface area of ponds by $57 \%$ and the total number of water bodies by more than 1 order of magnitude. The revised total surface area of all artificial water bodies across Queensland increased by $24 \%$ to just over $3248 \mathrm{~km}^{2}$ (Table A2).

Ponds were widely distributed across the state, but over $78 \%$ of ponds were located on grazing land, suggesting that stock dams represent the primary water body type (Fig. 2a). Over two-thirds of ponds were confined to regions of the state where rainfall isohyets were above $600 \mathrm{~mm}$ (Fig. 2b) and heavily concentrated in cropping and residential areas in the central and south-eastern parts of the state (Fig. 2c). These findings highlight the importance of striving to incorporate all artificial water bodies into flooded land emission assessments; omitting water bodies below a size threshold can lead to a dramatic underestimation of the total number of water bodies present and a considerable underestimate of the available surface area for $\mathrm{CH}_{4}$ emissions.

\section{2 $\mathrm{CH}_{4}$ emissions from ponds}

All 22 water bodies monitored in this study were shown to be emitters of $\mathrm{CH}_{4}$, and emission rates ranged from a minimum of $1 \mathrm{mg} \mathrm{m}^{-2} \mathrm{~d}^{-1}$ to a maximum of $5425 \mathrm{mg} \mathrm{m}^{-2} \mathrm{~d}^{-1}$ (Table A1). Only one water body (Mt Larcom 3) had a maximum rate below the reported upper range $\left(50 \mathrm{mg} \mathrm{CH}_{4} \mathrm{~m}^{-2} \mathrm{~d}^{-1}\right)$ for diffusive fluxes found in larger water bodies in this region (Grinham et al., 2011; Musenze et al., 2014). Mean flux rates of only four individual water bodies were below $50 \mathrm{mg} \mathrm{m}^{-2} \mathrm{~d}^{-1}$ (Table A1), suggesting ebullition to be the dominant emission pathway in these systems.

Grouping ponds according to their primary use resulted in no significant differences in emissions rates between irrigation dams, stock dams and urban lakes; however, weirs were significantly higher $\left(F_{(3,121)}=6.43, p<0.001\right)$ than all other 


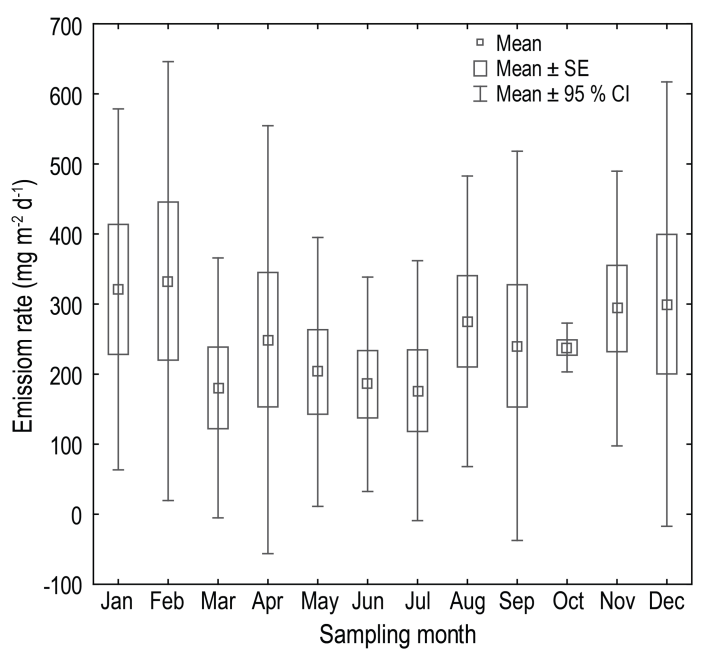

Figure 5. Monthly $\mathrm{CH}_{4}$ emissions from a single monitoring site on an urban lake (St Lucia 1) across the annual cycle. Values indicate mean emission rates $\pm \mathrm{SE}$ (standard error) and $95 \% \mathrm{CI}$ (confidence intervals).

categories (Fig. 3a). Mean emission rates were, however, higher in stock water bodies $\left(168 \mathrm{mg} \mathrm{m}^{-2} \mathrm{~d}^{-1}\right)$ compared with irrigation and urban bodies $\left(84\right.$ and $129 \mathrm{mg} \mathrm{m}^{-2} \mathrm{~d}^{-1}$, respectively). Weir water bodies had mean emission rates of $730 \mathrm{mg} \mathrm{m}^{-2} \mathrm{~d}^{-1}$, which is more than 4 times higher than those of any other category (Fig. 3a). Grouping ponds according to their GRanD size classes resulted in significantly higher emission rates $\left(\mathrm{KW} H_{(2,121)}=7.354, p<0.05\right)$ from ponds in the $10^{2}$ to $10^{3} \mathrm{~m}^{2}$ size class compared to $10^{4}$ to $10^{5} \mathrm{~m}^{2}$ (Fig. 3b). Overall, mean emissions decreased with increasing size class. Note that all weir sites fell into the smallest size category.

\subsection{Spatial and temporal variability in surface area and emission rate}

\subsubsection{Spatial and temporal variability within a single pond}

Observed emissions rates from the intensive spatial study, carried out in December 2017, ranged over 2 orders of magnitude from under 40 to over $3500 \mathrm{mg} \mathrm{m}^{-2} \mathrm{~d}^{-1}$ (Fig. 4). Emissions were highest in the shallow south-west sector of the pond, adjacent a large storm water inflow point, as well as along the western boundary where numerous overhanging riparian trees are located along with a second storm water inflow point (Fig. 4).

Monthly emissions were moderately variable across the annual cycle and mean rates ranged from 176 to $332 \mathrm{mg} \mathrm{m}^{-2} \mathrm{~d}^{-1}$. No significant difference in emissions rates $\left(\mathrm{KW} H_{(11,50)}=3.56, p=0.98\right)$ was observed between sampling events (Fig. 5). Mean rates observed during the

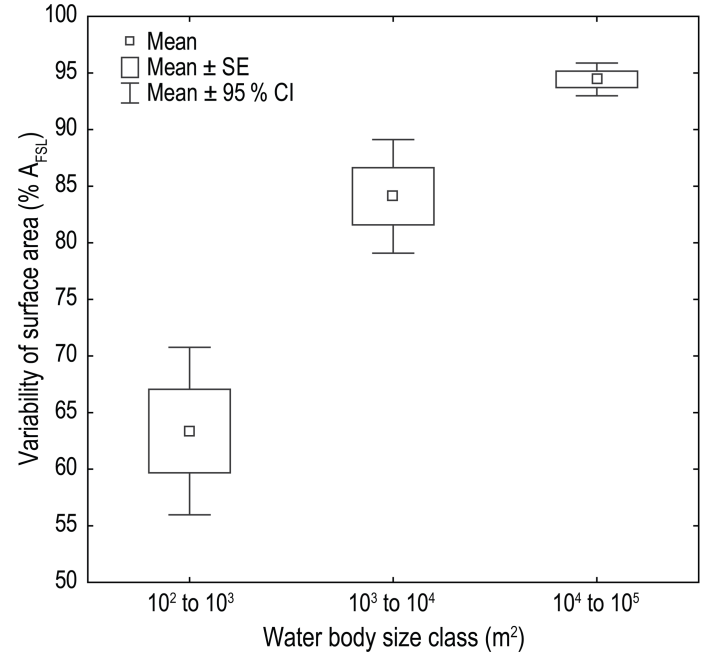

Figure 6. Variability in water surface area as a percentage of AFSL between three GRanD database size classes of ponds. Values indicate mean surface area $\pm \mathrm{SE}$ (standard error) and $95 \% \mathrm{CI}$ (confidence intervals).

monthly monitoring were similar to chamber rates from the intensive spatial study $\left(274 \mathrm{mg} \mathrm{m}^{-2} \mathrm{~d}^{-1}\right)$.

\subsubsection{Variability in water surface area across all monitored ponds}

Variability in water surface area is strongly related to water body size class (Fig. 6). Mean surface area within the smallest size class was only $64 \%$ of $A_{\mathrm{FSL}}$; this increased to $84 \%$ in the intermediate size class and to $94 \%$ in the largest size class (Fig. 6). Smaller ponds had a significantly lower surface area relative to $A_{\mathrm{FSL}}\left(\mathrm{KW} H_{(2,231)}=50.523, p<0.001\right)$ compared to larger size classes and were more variable (Fig. 6). Regional emissions estimates therefore need to correct for the differences in water body surface area relative to predicted $A_{\mathrm{FSL}}$, particularly in the smaller size classes.

\subsection{Effect of inundation on stock dam emissions}

The water surface area of a single stock dam ranged from 395 to $2808 \mathrm{~m}^{2}$ over a 40 -month period (Fig. 7a) with an outer band of $580 \mathrm{~m}^{2}$ undergoing frequent inundation cycles (May 2016 to December 2017 - Fig. 7a). Emissions rates from peripheral areas during an inundated period were significantly higher (more than 1 order of magnitude) compared with emissions when not inundated $\left(\mathrm{KW} H_{(1,10)}=6.818\right.$, $p<0.001$; Fig. 7b). In contrast emissions from central areas were over $100 \mathrm{mg} \mathrm{m}^{-2} \mathrm{~d}^{-1}$, which is more than double the peripheral area emission rates (Table A1). This modifier of rates will primarily impact emissions from smaller size classes which have greater variability in water surface area (Fig. 6). An additional implication is in the importance of designing monitoring studies where emissions rates are quanti- 

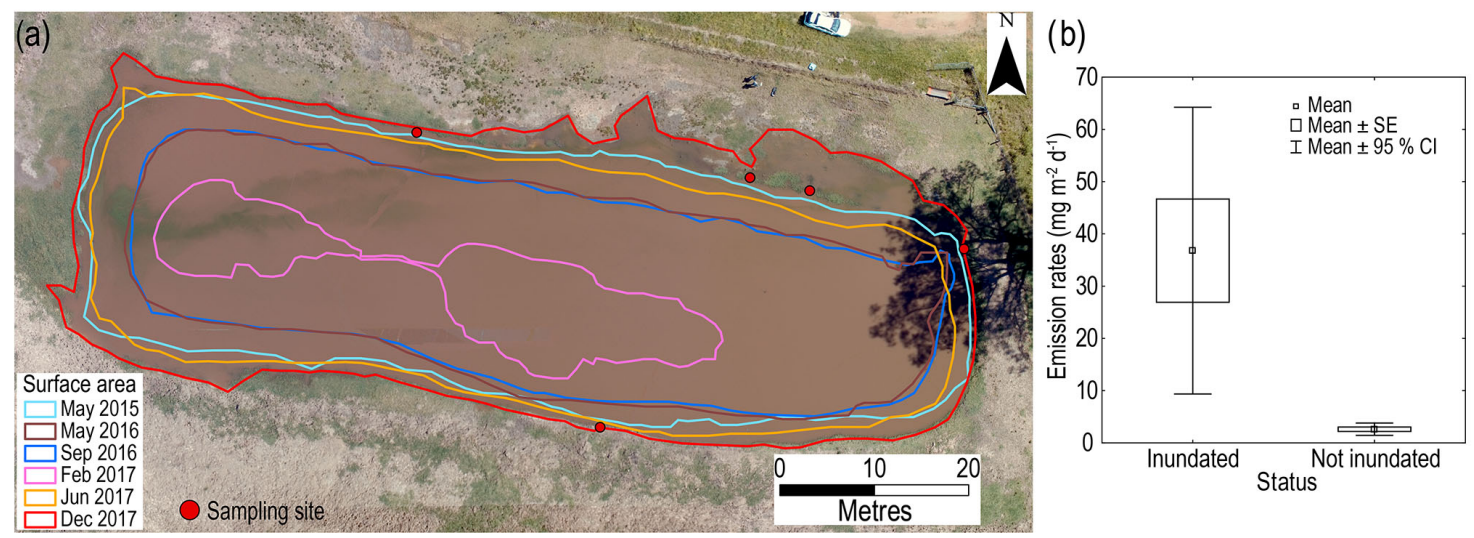

Figure 7. (a) Changes in surface area of stock dam (Gatton 4) over a 40-month period. (b) Emissions rates from peripheral zones during a period of inundation and no inundation. Values indicate mean emission rate \pm SE (standard error) and $95 \% \mathrm{CI}$ (confidence intervals).

fied from both peripheral and central areas for each system. Rates monitored only in peripheral areas will likely bias towards lower emissions, particularly if these have undergone recent inundation.

\section{Discussion}

\subsection{Relative importance of pond emissions to regional flooded land inventories}

The findings of this study demonstrate ponds are an underreported and important $\mathrm{CH}_{4}$ emission source in Queensland and likely also globally. These findings highlight the importance of striving to incorporate all artificial water bodies into flooded land emission assessments; omitting water bodies below a size threshold can lead to a substantial underestimation of the total number of water bodies present and a considerable underestimate of the available surface area for $\mathrm{CH}_{4}$ emissions. Mean annual $\mathrm{CH}_{4}$ fluxes from ponds for the state of Queensland ranged between 1.7 and 1.9 million $\mathrm{tCO}_{2}$ eq. (Table 1) depending on the scaling approach. Given that ponds represent $33.5 \%$ of the total flooded lands surface area in Queensland and emission rates are equivalent to larger water bodies in the region (Musenze et al., 2014; Sturm et al., 2014), ponds represent one-third of total emissions from flooded lands in Queensland. Remarkably, mean total emissions from ponds represent approximately $10 \%$ of Queensland's land use, land use change and forestry sector (NGERS, 2015) emissions using either scaling approach.

Future regional and global emissions estimates would be greatly improved with the inclusion of ponds, as their proliferation has been noted in five continents. In the continental United States ponds have been shown to cover $20 \%$ of the total artificial water body surface area (Smith et al., 2002); in South Africa there are an estimated 500000 ponds (Mantel et al., 2010); in Czechoslovakia ponds make up over $30 \%$ of the total artificial water body surface area (Vacek, 1983); and in India ponds are estimated to comprise $6238 \mathrm{~km}^{2}$, or over $25 \%$ of India's artificial water body surface area (Panneer Selvam et al., 2014).

\subsection{Pond emission pathways}

Emissions rates from ponds observed in this study are consistent with ebullition being the dominant pathway. Diffusive emissions from studies of three larger water bodies in the region found the upper limit for diffusive emission was $50 \mathrm{mg} \mathrm{m}^{-2} \mathrm{~d}^{-1}$ (Grinham et al., 2011; Musenze et al., 2014) and only five ponds had emission rates below this level. Ebullition was observed at all ponds with maximum rates all in excess of $50 \mathrm{mg} \mathrm{m}^{-2} \mathrm{~d}^{-1}$, with the exception of only one stock dam (Mt Larcom 3) where the maximum rate was $19 \mathrm{mg} \mathrm{m}^{-2} \mathrm{~d}^{-1}$. This is a consistent finding with larger water bodies in the region where ebullition has been shown to dominate total emissions (Grinham et al., 2011; Sturm et al., 2014). The relatively higher emissions from smaller pond size classes is consistent with previous observations of increased ebullition activity in shallow zones, particularly water depths less than $5 \mathrm{~m}$ (Keller and Stallard, 1994; Joyce and Jewell, 2003; Sturm et al., 2014). Virtually all ponds within the smaller size classes would be less than $5 \mathrm{~m}$ deep. In addition, ponds trap large quantities of sediment and organic material (Neil and Mazari, 1993; Verstraeten and Prosser, 2008) and these deposition zones have been identified as methane ebullition hotspots in larger water bodies (Sobek et al., 2012; Maeck et al., 2013). The patterns in emissions from the intensive spatial study in an urban lake, where shallow areas adjacent storm water inflows were shown to be ebullition hotspots, have also been observed in larger water bodies were ebullition activity was highest adjacent to catchment inflows (DelSontro et al., 2011; Grinham et al., 2017; de Mello et al., 2017). The emissions from small weirs were clearly dominated by ebullition, which is consistent with emissions 
Table 1. Summary of Queensland small water bodies classified using two different relative size classifications. The number of water bodies, corrected surface area of size class and total mean annual emissions. Approach 1: emissions for water bodies less than $3500 \mathrm{~m}^{2}$ were assumed to be stock dams and larger water bodies were assumed to be irrigation dams (Fig. 3a). Approach 2: emissions for GRanD size classes were taken from Fig. 3b. However, weir emissions were omitted as these are not relevant at the regional scale.

\begin{tabular}{|c|c|c|c|c|c|}
\hline \multicolumn{6}{|c|}{ Approach 1} \\
\hline \multirow[t]{2}{*}{ Water body size $\left(\mathrm{m}^{2}\right)$} & \multirow[t]{2}{*}{ Number } & \multirow[t]{2}{*}{ Surface area $\left(\mathrm{km}^{2}\right)$} & \multicolumn{3}{|c|}{ Total emissions ( $\mathrm{tCO}_{2}$ eq. $\mathrm{yr}^{-1}$ ) } \\
\hline & & & Mean & Lower limit & Upper limit \\
\hline$<3500$ & 227397 & 243 & 507633 & 278205 & 926267 \\
\hline 3500 to $10^{5}$ & 65949 & 844 & 1158069 & 782244 & 1714458 \\
\hline Total & 293346 & 1087 & 1665702 & 1060448 & 2640725 \\
\hline \multicolumn{6}{|c|}{ Approach 2} \\
\hline \multirow[t]{2}{*}{ Water body size $\left(\mathrm{m}^{2}\right)$} & Number & Surface area $\left(\mathrm{km}^{2}\right)$ & \multicolumn{3}{|c|}{ Total emissions ( $\mathrm{tCO}_{2}$ eq. $\mathrm{yr}^{-1}$ ) } \\
\hline & & & Mean & Lower limit & Upper limit \\
\hline $10^{2}$ to $10^{3}$ & 108526 & 50 & 97302 & 35436 & 267177 \\
\hline $10^{3}$ to $10^{4}$ & 163803 & 400 & 868201 & 513740 & 1467225 \\
\hline $10^{4}$ to $10^{5}$ & 21017 & 637 & 759247 & 462561 & 1246228 \\
\hline Total & & & 1724749 & 1011736 & 2980629 \\
\hline
\end{tabular}

from three larger weirs where rates ranged from 1000 to over $6000 \mathrm{mg} \mathrm{m}^{-2} \mathrm{~d}^{-1}$ (Bednař́k et al., 2017). Weirs intercept the primary streamflow pathways and will likely cause large quantities of catchment-derived organic matter to deposit within the weir body which, coupled to the shallow nature, results in high rates of ebullition. Overall, the rates observed for all categories, except irrigation dams, were in the upper range of reservoir areal flux rates reported in global reviews (St. Louis et al., 2000; Bastviken et al., 2011; Deemer et al., 2016), reflecting the dominance of the ebullition pathway in ponds. An additional consideration for future studies of ebullition patterns in ponds stems from recent studies of reservoirs which found significant changes in ebullition intensity and ebullition distribution as water levels decrease (Beaulieu et al., 2018; Hilgert et al., 2019). Under decreasing water levels, deeper zones of ponds may begin bubbling or increase the intensity of bubbling; this could potentially offset the reduction in surface available for emissions and total emissions would remain relatively constant.

\subsection{Challenges in scaling emissions}

Efforts to develop flooded land emission inventories rely heavily on the emission rate used to scale the surface area of water bodies within selected categories. Given the high variability in emission rates within and between individual ponds and relatively low replication, it is critical to select an appropriate measure of centrality (arithmetic mean, geometric mean or median) in order to scale regionally and globally (Downing, 2010). For rice paddies, septic tanks, peatlands and natural waters (Aselmann and Crutzen, 1989; Dise et al.,
1993; Diaz-Valbuena et al., 2011; Bridgham et al., 2006), the geometric mean has been applied. Likewise, in this study the log-normal distribution of emissions data indicated the geometric mean as the most appropriate measure and the total emission rates using this measure fell within the reported range from larger artificial water bodies in the region (Grinham et al., 2011; Sturm et al., 2014). However, the geometric means for all water body categories and size classes were less than half of their respective arithmetic mean values (Fig. A6). For irrigation, stock and urban water bodies, geometric mean values were actually outside of $95 \%$ confidence interval limit for the arithmetic mean (Fig. A6a, b). Geometric mean and median values were similar across all water body categories and size classes, and these measures, therefore, represent conservative emissions rates from ponds. This raises an important issue with scaling ebullition-dominated water bodies as there is always going to be a high likelihood of detecting a small number of very high rates which will invariably give rise to log-normal data distributions. Future studies will focus on determining whether the conservative estimates generated through the use of geometric means approximate the true emissions from ponds.

\section{Future research}

Continued efforts to quantify regional pond abundance, particularly smaller size classes, should be a research priority as this will greatly improve the surface area estimate of flooded lands used for upscaling greenhouse gas emissions as well as their role in the global carbon cycle. The increased cov- 
erage, availability and resolution of satellite imagery as well as more sophisticated methods to identify water bodies (Verpoorter et al., 2014) will support these efforts. However, it is critical to continually update regional assessments as the annual increase in farm ponds has been estimated to be as high as $60 \%$ in some parts of the globe (Downing and Duarte, 2009). Regional assessments should also correct for differences in pond surface area, particularly in the smaller size classes, as this study has demonstrated actual surface area can be significantly smaller than the surface area at full supply level $\left(A_{\mathrm{FSL}}\right)$. An additional consideration is to ensure pond emission studies from different regions include all relevant ponds types. For example, the use of ponds to increase groundwater recharge is widespread across Southeast Asia (Giordano, 2009) and these would need to be included in regional inventories.

Increasing both the number and type of pond within each size class in emissions monitoring studies should be a research priority. This will allow increased confidence in the selection of an appropriate measure of centrality as well as reducing uncertainty in the expected range of emission rates within each pond category. When designing a monitoring study it is important to ensure emissions rates are quantified from both peripheral and central areas for each pond. This study demonstrated that measurements taken only in peripheral areas will likely bias towards lower emissions particularly in ponds that experience rapid changes in water level and, therefore, inundation status of peripheral areas. However, this was limited to a single stock dam and additional pond types and size classes must be examined before more confident generalisations can be made.
The high spatial variability in emission rates within ponds noted from this study highlights the importance of ensuring chambers cover the widest possible spatial scale during a measurement campaign. This will increase the likelihood of detecting ebullition zones which are likely the dominant emission pathway. However, this finding was from a single urban lake and additional long-term temporal studies along with high-resolution spatial surveys of different pond types and size classes are required to identify the drivers of pond emission pathways. Research into both pond surface area and $\mathrm{CH}_{4}$ emission rates will allow greater understanding of their importance to flooded land emission inventories at both regional and global scales.

Data availability. The data that support the findings of this study are available from the corresponding author upon request. 


\section{Appendix A}

Table A1. Selected characteristics from individual ponds showing primary use of each system; surrounding land use type; location of system latitude (Lat) and longitude (Long); average surface area (SA) in $\mathrm{m}^{2}$; mean, median, minimum (Min) and maximum (Max) methane emission rates $\left(\mathrm{mg} \mathrm{m}^{-2} \mathrm{~d}^{-1}\right)$; and number of chamber measurements on individual systems (Cham). Primary uses included the following: irrigation for cropping; stock watering for cattle and horses; urban uses included storm water management and aesthetic purposes; weirs for water supply and streamflow monitoring. ${ }^{\mathrm{a}}$ indicates water bodies where repeat sampling was conducted; ${ }^{\mathrm{b}}$ indicates water bodies where deployments of less than $24 \mathrm{~h}$ were conducted. Geom mean is the geometric mean; Arithm mean is the arithmetic mean.

\begin{tabular}{|c|c|c|c|c|c|c|c|c|c|c|c|}
\hline Area & Primary use & Land use & Lat & Long & SA & Arithm mean & Geom mean & Median & Min & Max & Cham \\
\hline Gatton $1^{\mathrm{a}}$ & Irrigation & Grazing & -27.5541 & 152.3412 & 25903 & 785 & 590 & 527 & 238 & 1648 & 6 \\
\hline Gatton $2^{\mathrm{a}}$ & Irrigation & Grazing & -27.5548 & 152.3394 & 3450 & 581 & 170 & 140 & 17 & 2261 & 6 \\
\hline Gatton $3^{a}$ & Stock & Grazing & -27.5615 & 152.3434 & 1041 & 1149 & 905 & 980 & 314 & 2007 & 12 \\
\hline Gatton $4^{\mathrm{a}}$ & Stock & Grazing & -27.5625 & 152.3447 & 1893 & 63 & 55 & 63 & 20 & 109 & 6 \\
\hline Gatton 5 & Irrigation & Cropland & -27.5537 & 152.3503 & 30458 & 129 & 122 & 110 & 89 & 186 & 3 \\
\hline Gatton 6 & Stock & Cropland & -27.5546 & 152.3488 & 446 & 1229 & 724 & 844 & 93 & 3635 & 6 \\
\hline Port precinct ${ }^{b}$ & Urban & Settlement & -27.3917 & 153.1676 & 38285 & 144 & 57 & 68 & 8 & 357 & 3 \\
\hline St Lucia $1^{\mathrm{a}}$ & Urban & Settlement & -27.4996 & 153.0163 & 22727 & 632 & 282 & 279 & 36 & 3558 & 16 \\
\hline St Lucia 2 & Urban & Settlement & -27.4984 & 153.0173 & 4291 & 92 & 83 & 76 & 51 & 148 & 3 \\
\hline St Lucia 3 & Urban & Settlement & -27.4981 & 153.0167 & 1755 & 56 & 49 & 43 & 27 & 115 & 5 \\
\hline Pinjarra $1^{\mathrm{a}}$ & Irrigation & Grazing & -27.5372 & 152.9139 & 56782 & 34 & 15 & 20 & 2 & 122 & 10 \\
\hline Pinjarra 2 & Stock & Grazing & -27.5294 & 152.9242 & 1943 & 205 & 59 & 277 & 2 & 335 & 3 \\
\hline Pinjarra 3 & Stock & Grazing & -27.5294 & 152.9227 & 210 & 193 & 143 & 107 & 67 & 404 & 3 \\
\hline Oxenford & Urban & Settlement & -27.8924 & 153.2997 & 36938 & 97 & 94 & 81 & 76 & 133 & 6 \\
\hline Mt Larcom 1 & Stock & Grazing & -23.8008 & 150.9558 & 5025 & 574 & 37 & 18 & 1 & 2051 & 5 \\
\hline Mt Larcom 2 & Stock & Grazing & -23.806 & 150.9574 & 1256 & 48 & 45 & 49 & 26 & 70 & 3 \\
\hline Mt Larcom 3 & Stock & Grazing & -23.8015 & 150.9446 & 16093 & 17 & 17 & 18 & 14 & 19 & 3 \\
\hline Fig Tree Park & Urban & Settlement & -27.5394 & 152.9682 & 8357 & 709 & 301 & 289 & 19 & 1850 & 5 \\
\hline Greenbank $^{\mathrm{b}}$ & Stock & Settlement & -27.7249 & 152.9779 & 575 & 290 & 166 & 188 & 29 & 755 & 4 \\
\hline Lake Alford ${ }^{\mathrm{b}}$ & Urban & Settlement & -26.2152 & 152.6848 & 21689 & 49 & 29 & 62 & 5 & 79 & 3 \\
\hline Mt Coot-tha ${ }^{\mathrm{a}}$ & Weir & Forest & -27.4763 & 152.9642 & 580 & 2493 & 1405 & 2337 & 368 & 5425 & 6 \\
\hline Indooroopilly & Weir & Settlement & -27.5027 & 152.988 & 436 & 413 & 274 & 314 & 77 & 947 & 4 \\
\hline
\end{tabular}

Table A2. Surface area (SA) of Queensland artificial water bodies within each GRanD database size class showing the official land use assessment estimates (QLUMP, 2018) and the revised estimates for the smallest three size classes found in this study.

\begin{tabular}{lrr}
\hline GRanD size class $\left(\mathrm{m}^{2}\right)$ & QLUMP SA $\left(\mathrm{km}^{2}\right)$ & Revised SA $\left(\mathrm{km}^{2}\right)$ \\
\hline $10^{2}$ to $10^{3}$ & 0.005 & 50.3 \\
$10^{3}$ to $10^{4}$ & 8.4 & 400 \\
$10^{4}$ to $10^{5}$ & 459 & 637 \\
$10^{5}$ to $10^{6}$ & 605 & 605 \\
$10^{6}$ to $10^{7}$ & 555 & 555 \\
$10^{7}$ to $10^{8}$ & 553 & 553 \\
$10^{8}$ to $10^{9}$ & 448 & 448 \\
\hline Total & 2629 & 3248 \\
\hline
\end{tabular}




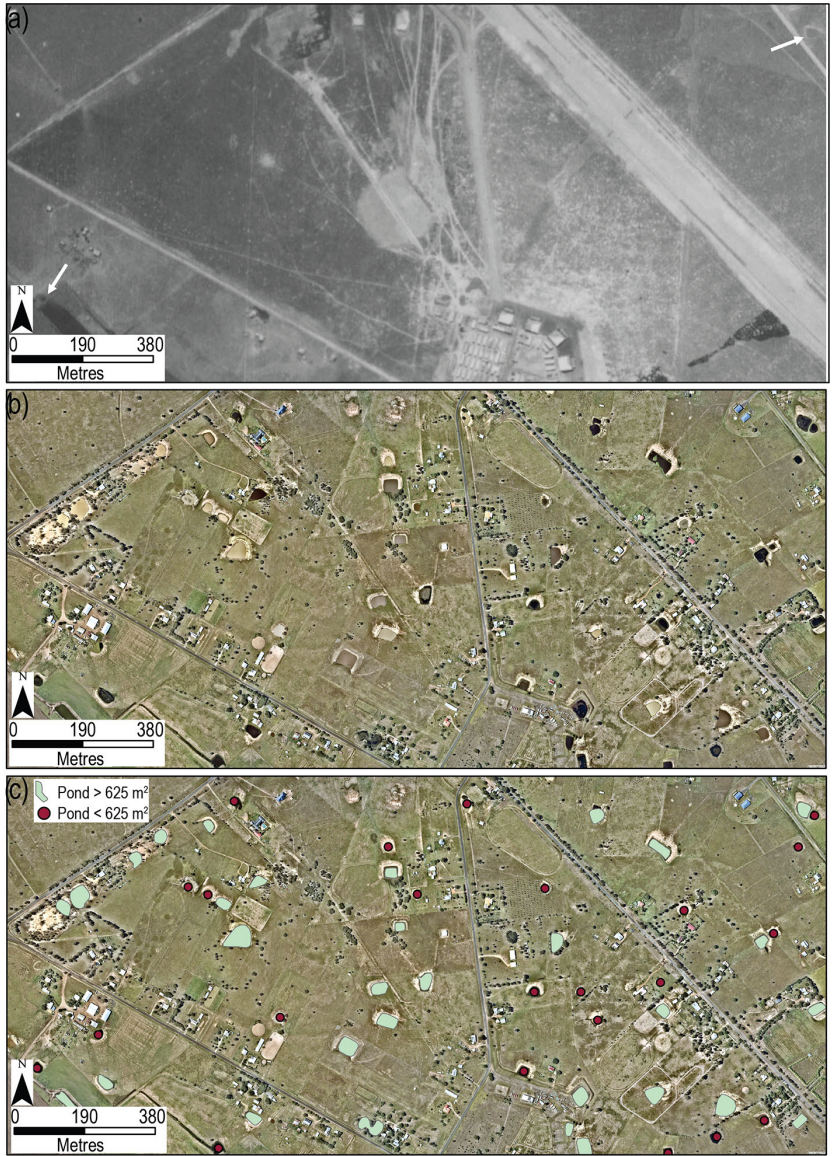

Figure A1. Historical changes in pond distribution from a $2.7 \mathrm{~km}^{2}$ area in south-east Queensland, Mt Tarampa $\left(27^{\circ} 27^{\prime} 44^{\prime \prime} \mathrm{S}\right.$, $152^{\circ} 28^{\prime} 59^{\prime \prime} \mathrm{E}$ ). (a) 1944 aerial images showing 2 ponds indicated by white arrows, (b) 2017 aerial image showing 54 ponds and (c) showing the relative distribution of ponds from the Reservoir $\left(>625 \mathrm{~m}^{2}\right)$ database and the Water Storage Point $\left(<625 \mathrm{~m}^{2}\right)$ database - together this results in a density of 20 ponds $\mathrm{km}^{-2}$.

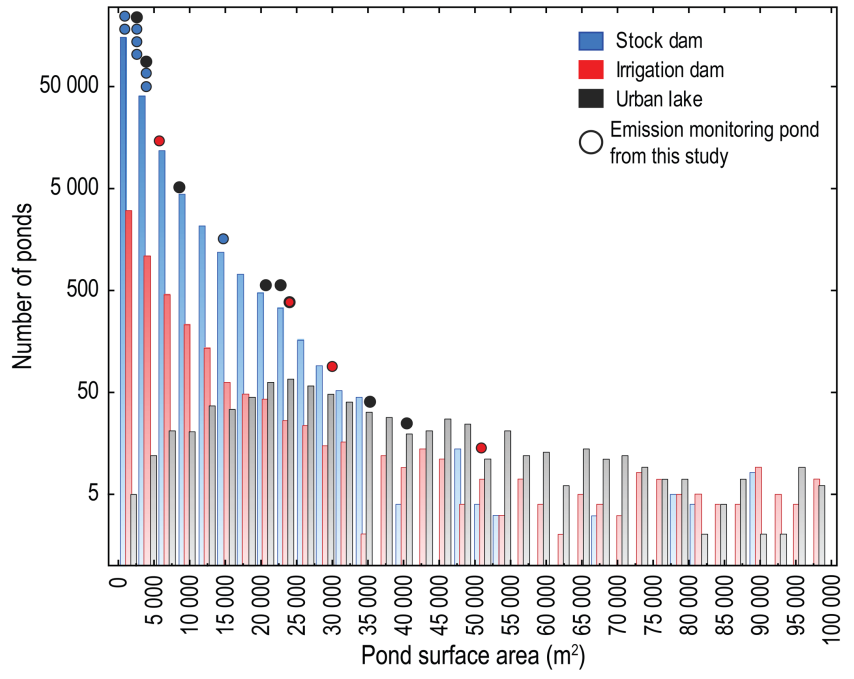

Figure A2. Pond size from the emission study relative to the histogram of the regional pond distribution of stock dams, irrigation dams and urban lakes. The surface area of pond used in the emission study (Table A1). Histogram of regional distribution of ponds was developed from the QLUMP, Reservoir and Water Storage Points databases and separated into pond type depending on surrounding land use: "grazing native vegetation" for stock dams; "production from irrigated agriculture and plantations" for irrigation dams; "intensive uses" for urban lakes with "mining" and "manufacturing" land use within "intensive uses" were removed to ensure only urban areas were selected. To incorporate the distribution of ponds within the Water Storage Points database, it was assumed this would match the distribution from the 100 individual ponds examined in Sect. 2.2 to determine their average surface area. 


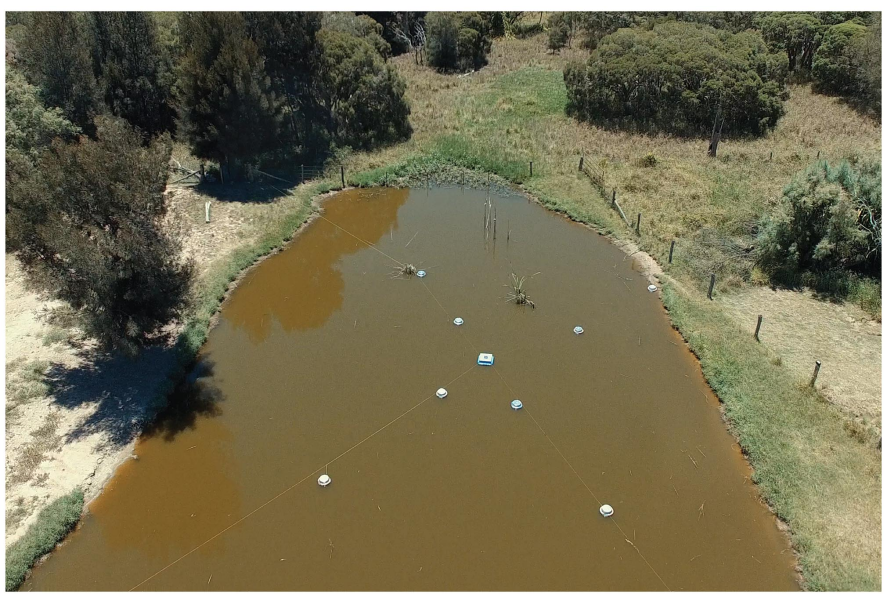

Figure A3. An oblique drone image showing a nine-floating-chamber deployment set-up targeting peripheral and central zones on a stock watering dam (Gatton 3).
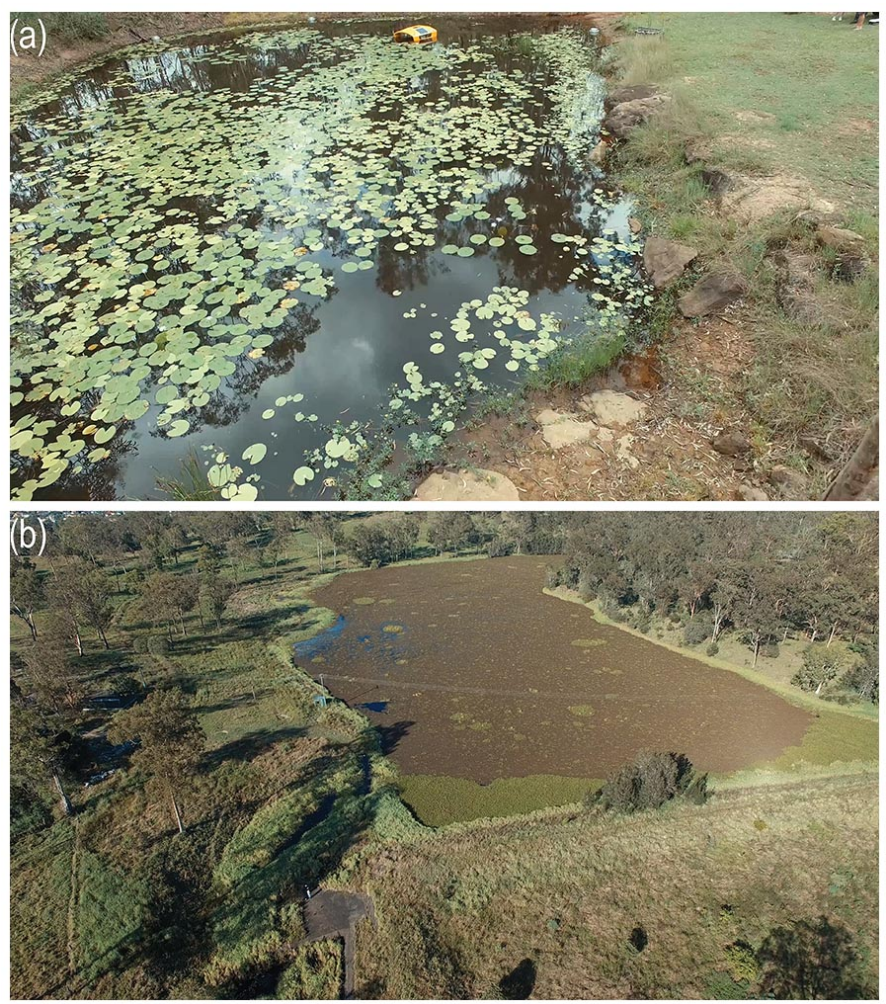

Figure A4. Oblique drone images showing natural obstacles for pond chamber deployments from (a) emergent macrophytes and (b) floating aquatic weeds. 

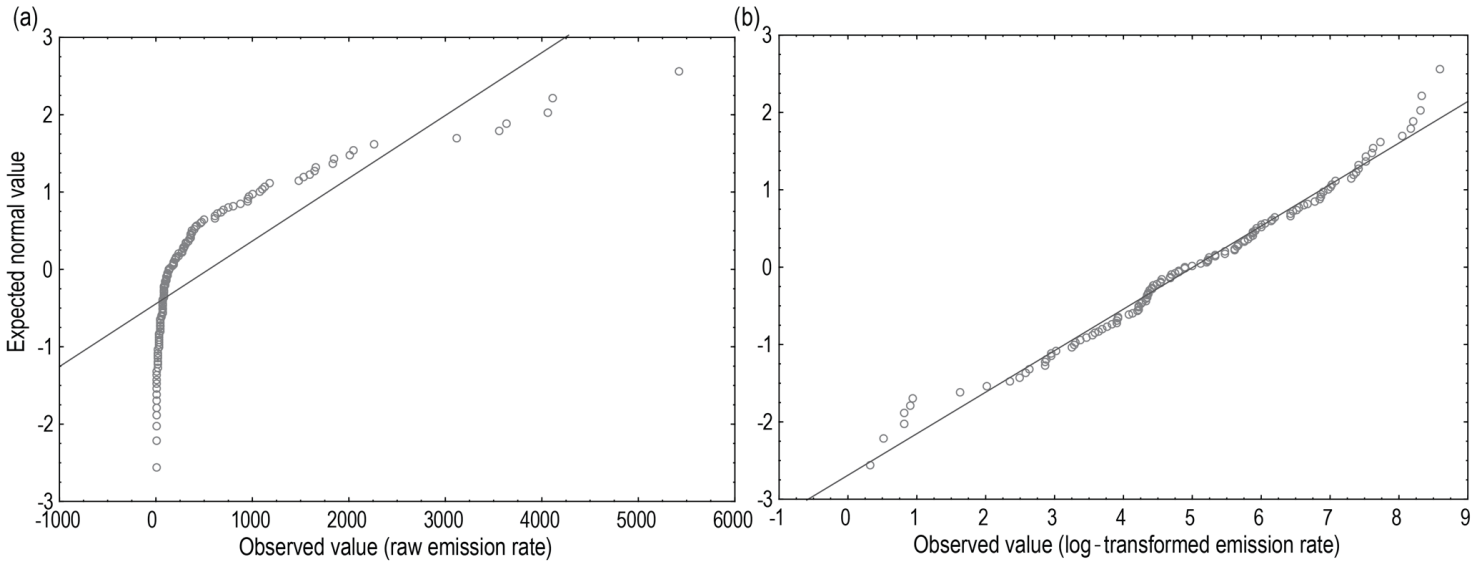

Figure A5. Normal probability plots for (a) raw methane emissions and (b) log-transformed emissions data. The Shapiro-Wilks test $p$ value for raw emissions data was $<0.001$ and failed the normality test; $p$ value for log-transformed emissions data was 0.081 , indicating data were normally distributed.

(a)

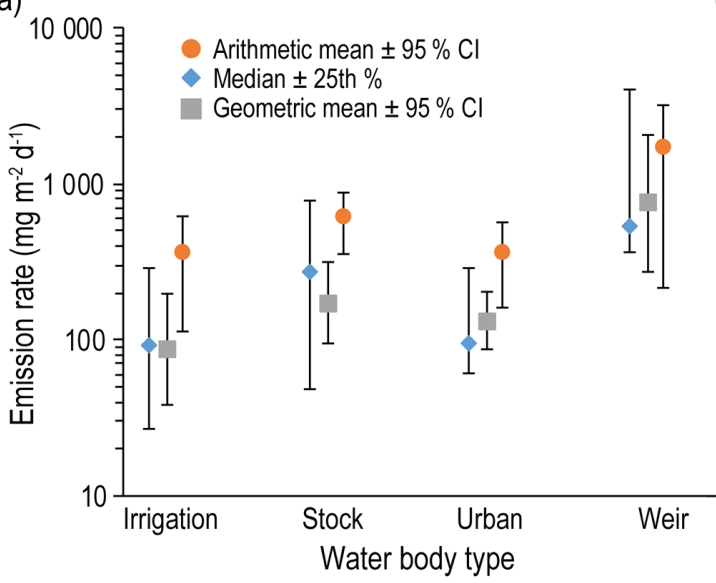

(b)

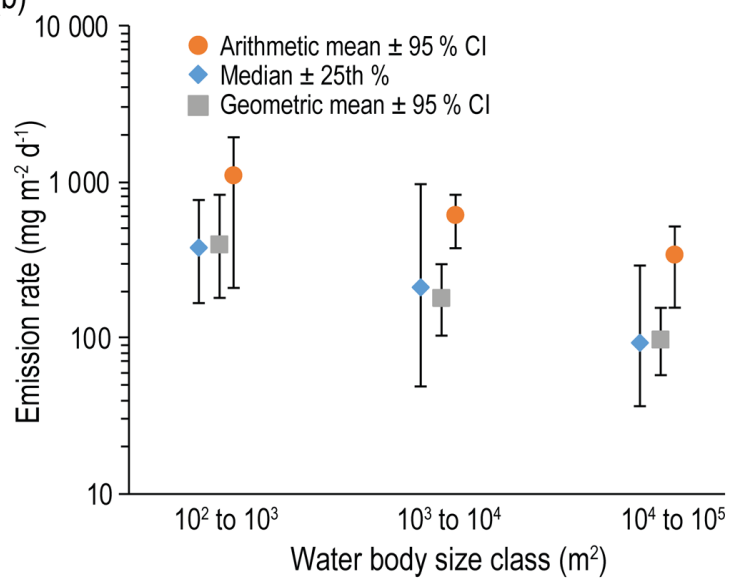

Figure A6. Three measures of centrality for methane emissions across (a) four categories of small water bodies (irrigation dams, stock dams, urban lakes and weirs) and (b) three GRanD water body size classes. Errors for each measure are as follows: median emission rates and interquartile range $( \pm 25$ th $\%)$, arithmetic and geometric mean emission rates and $95 \%$ confidence intervals $( \pm 95 \% \mathrm{CI})$. 
Author contributions. AG conceived, designed and conducted the study and co-wrote the manuscript; CDE, CEL, DB and BS conceived, designed the study and contributed to the manuscript; SA, ND and MD conducted the study and contributed to the manuscript.

Competing interests. The authors declare that they have no conflict of interest.

Acknowledgements. We are grateful to the reviewers for their helpful comments and suggestions. We gratefully acknowledge the following for providing access to ponds: Ross and Lorraine Prange, Geoff and Maureen Gale, Mark Bauer, Stuart Green and Thomas Connolly. In addition, we are grateful for the background information regarding the primary use of the ponds. We gratefully acknowledge Markus Fluggen for laboratory and logistical support.

Edited by: Marnik Vanclooster

Reviewed by: Carluer Nadia and one anonymous referee

\section{References}

Aben, R. C., Barros, N., Van Donk, E., Frenken, T., Hilt, S., Kazanjian, G., Lamers, L. P., Peeters, E. T., Roelofs, J. G., and Domis, L. N. S.: Cross continental increase in methane ebullition under climate change, Nat. Commun., 8, 1-8, 2017.

ABS: Australian Bureau of Statistics: Queensland region, available at: http://stat.abs.gov.au/, last access: 14 March 2018.

Albert, S., Leon, J. X., Grinham, A. R., Church, J. A., Gibbes, B. R., and Woodroffe, C. D.: Interactions between sea-level rise and wave exposure on reef island dynamics in the Solomon Islands, Environ. Res. Lett., 11, 054011, https://doi.org/10.1088/17489326/11/5/054011, 2016.

Allen, D., Mendham, D., Cowie, A., Wang, W., Dalal, R., and Raison, R.: Nitrous oxide and methane emissions from soil are reduced following afforestation of pasture lands in three contrasting climatic zones, Soil Res., 47, 443-458, 2009.

Aselmann, I. and Crutzen, P.: Global distribution of natural freshwater wetlands and rice paddies, their net primary productivity, seasonality and possible methane emissions, J. Atmos. Chem., 8, 307-358, 1989.

Bastviken, D., Cole, J., Pace, M., and Tranvik, L.: Methane emissions from lakes: Dependence of lake characteristics, two regional assessments, and a global estimate, Global Biogeochem. Cy., 18, GB4009, https://doi.org/10.1029/2004GB002238, 2004.

Bastviken, D., Santoro, A. L., Marotta, H., Pinho, L. Q., Calheiros, D. F., Crill, P., and Enrich-Prast, A.: Methane Emissions from Pantanal, South America, during the Low Water Season: Toward More Comprehensive Sampling, Environ. Sci. Technol., 44, 5450-5455, 2010.

Bastviken, D., Tranvik, L. J., Downing, J. A., Crill, P. M., and Enrich-Prast, A.: Freshwater methane emissions offset the continental carbon sink, Science, 331, p. 50, 2011.

Bastviken, D., Sundgren, I., Natchimuthu, S., Reyier, H., and Gålfalk, M.: Technical Note: Cost-efficient approaches to measure carbon dioxide $\left(\mathrm{CO}_{2}\right)$ fluxes and concentrations in terrestrial and aquatic environments using mini loggers, Biogeosciences, 12, 3849-3859, https://doi.org/10.5194/bg-12-3849-2015, 2015.

Beaulieu, J. J., Balz, D. A., Birchfield, M. K., Harrison, J. A., Nietch, C. T., Platz, M., Squier, W. C., Waldo, S., Walker, J. T., White, K. M., and Young, J. L.: Effects of an experiemntal waterlevel drawdown on methane emissions from a eutrophic reservoir, Ecosystems, 21, 657-674, 2018.

Bednařík, A., Blaser, M., Matoušů, A., Hekera, P., and Rulik, M.: Effect of weir impoundments on methane dynamics in a river, Sci. Total Environ., 584, 164-174, 2017.

Boardman, J. and Foster, I. D.: The potential significance of the breaching of small farm dams in the Sneeuberg region, South Africa, J. Soil. Sediment., 11, 1456-1465, 2011.

Boon, P. I., Mitchell, A., and Lee, K.: Effects of wetting and drying on methane emissions from ephemeral floodplain wetlands in southeastern Australia, Hydrobiologia, 357, 73-87, 1997.

Bridgham, S. D., Patrick Megonigal, J., Keller, J. K., Bliss, N. B., and Trettin, C.: The carbon balance of North American wetlands, Wetlands, 26, 889-916, 2006.

Callow, J. and Smettem, K.: The effect of farm dams and constructed banks on hydrologic connectivity and runoff estimation in agricultural landscapes, Environ. Modell. Softw., 24, 959-968, 2009.

Chumchal, M. M., Drenner, R. W., and Adams, K. J.: Abundance and size distribution of permanent and temporary farm ponds in the southeastern Great Plains, Inland Waters, 6, 258-264, 2016.

Cole, J. J., Bade, D. L., Bastviken, D., Pace, M. L., and Van de Bogert, M.: Multiple approaches to estimating air-water gas exchange in small lakes, Limnol. Oceanogr.-Meth., 8, 285-293, 2010.

Deemer, B. R., Harrison, J. A., Li, S., Beaulieu, J. J., DelSontro, T., Barros, N., Bezerra-Neto, J. F., Powers, S. M., dos Santos, M. A., and Vonk, J. A.: Greenhouse gas emissions from reservoir water surfaces: a new global synthesis, BioScience, 66, 949-964, 2016.

Dell Inc.: Dell Statistica (data analysis software system), version 13, available at: http://www.statsoft.com/Products/ STATISTICA-Features (last access: 20 September 2018), 2016.

DelSontro, T., Kunz, M. J., Kempter, T., Wüest, A., Wehrli, B., and Senn, D. B.: Spatial heterogeneity of methane ebullition in a large tropical reservoir, Environ. Sci. Technol., 45, 9866-9873, 2011.

de Mello, N. A. S. T., Brighenti, L. S., Barbosa, F. A. R., Staehr, P. A., and Bezerra Neto, J. F.: Spatial variability of methane $\left(\mathrm{CH}_{4}\right)$ ebullition in a tropical hypereutrophic reservoir: Silted areas as a bubble hot spot, Lake Reserv. Manage., 34, 1-10, 2017.

DEWS: Guidance on referable dams planning, Department of Energy and Water Supply, Queensland, Australia, 2017.

Diaz-Valbuena, L. R., Leverenz, H. L., Cappa, C. D., Tchobanoglous, G., Horwath, W. R., and Darby, J. L.: Methane, carbon dioxide, and nitrous oxide emissions from septic tank systems, Environ. Sci. Technol., 45, 2741-2747, 2011.

Dise, N. B., Gorham, E., and Verry, E. S.: Environmental factors controlling methane emissions from peatlands in northern Minnesota, J. Geophys. Res.-Atmos., 98, 10583-10594, 1993.

Downing, J., Cole, J., Middelburg, J., Striegl, R., Duarte, C., Kortelainen, P., Prairie, Y., and Laube, K.: Sediment organic carbon burial in agriculturally eutrophic impoundments over the last century, Global Biogeochem. Cy., 22, GB1018, https://doi.org/10.1029/2006GB002854, 2008. 
Downing, J. A.: Emerging global role of small lakes and ponds: little things mean a lot, Limnetica, 29, 9-24, 2010.

Downing, J. A. and Duarte, C. M.: Abundance and size distribution of lakes, ponds and impoundments, in: Encyclopedia of Inland Waters, edited by: Likens, G. E., Elsevier, Oxford, UK, 469-478, 2009

Downing, J. A., Prairie, Y. T., Cole, J. J., Duarte, C. M., Tranvik, L. J., Striegl, R. G., McDowell, W. H., Kortelainen, P., Caraco, N. F., Melack, J. M., and Middelburg, J. J.: The global abundance and size distribution of lakes, ponds, and impoundments, Limnol. Oceanogr., 51, 2388-2397, 2006.

Fairchild, G. W., Robinson, C., Brainard, A. S., and Coutu, G. W.: Historical changes in the distribution and abundance of constructed ponds in response to changing population density and land use, Landscape Res., 38, 593-606, 2013.

Gålfalk, M., Bastviken, D., Fredriksson, S., and Arneborg, L.: Determination of the piston velocity for water-air interfaces using flux chambers, acoustic Doppler velocimetry, and IR imaging of the water surface, J. Geophys. Res.-Biogeo., 118, 770-782, 2013.

Giordano, M.: Global groundwater? Issues and solutions, Annu. Rev. Env. Resour., 34, 153-178, 2009.

Grinham, A., Dunbabin, M., Gale, D., and Udy, J.: Quantification of ebullitive and diffusive methane release to atmosphere from a water storage, Atmos. Environ., 45, 7166-7173, 2011.

Grinham, A., Dunbabin, M., and Albert, S.: Importance of sediment organic matter to methane ebullition in a sub-tropical freshwater reservoir, Sci. Total Environ., 621, 1199-1207, 2017.

Habets, F., Philippe, E., Martin, E., David, C. H., and Leseur, F.: Small farm dams: impact on river flows and sustainability in a context of climate change, Hydrol. Earth Syst. Sci., 18, 42074222, https://doi.org/10.5194/hess-18-4207-2014, 2014.

Hamilton, A. J., Conort, C., Bueno, A., Murray, C. G., and Grove, J. R.: Waterbird use of farm dams in south-eastern Australia: abundance and influence of biophysical and landscape characteristics, Avian Res., 8, 2, https://doi.org/10.1186/s40657-016-0058$\mathrm{x}, 2017$.

Harrison, J. A., Deemer, B. R., Birchfield, M. K., and O'Malley, M. T.: Reservoir water-level drawdowns accelerate and amplify methane emission, Environ. Sci. Technol., 51, 1267-1277, 2017.

Hilgert, S., Vicente Scapulatempo Fernandes, C., and Fuchs, S.: Redistribution of methane emission hot spots under drawdown conditions, Sci. Total Environ., 646, 958-971, 2019.

IPCC: 2006 IPCC Guidelines for National Greenhouse Gas Inventories, Prepared by the National Greenhouse Gas Inventories Programme, edited by: Eggleston, H. S., Buendia, L., Miwa, K., Ngara, T., and Tanabe, K., IGES, Japan, 2006.

IPCC: AR5 WG, "Climate Change 2013: The Physical Science Basis - Anthropogenic and Natural Radiative Forcing Supplementary Material", Cambridge University Press, 2013.

Joyce, J. and Jewell, P. W.: Physical controls on methane ebullition from reservoirs and lakes, Environ. Eng. Geosci., 9, 167-178, 2003.

Keller, M. and Stallard, R. F.: Methane emission by bubbling from Gatun Lake, Panama, J. Geophys. Res.-Atmos., 99, 8307-8319, 1994.

Klingaman, N. P., Woolnough, S., and Syktus, J.: On the drivers of inter-annual and decadal rainfall variability in Queensland, Australia, Int. J. Climatol., 33, 2413-2430, 2013.
Lehner, B. and Döll, P.: Development and validation of a global database of lakes, reservoirs and wetlands, J. Hydrol., 296, 1-22, 2004.

Lehner, B., Liermann, C. R., Revenga, C., Vörösmarty, C., Fekete, B., Crouzet, P., Döll, P., Endejan, M., Frenken, K., and Magome, J.: High-resolution mapping of the world's reservoirs and dams for sustainable river-flow management, Front. Ecol. Environ., 9, 494-502, 2011.

Limpert, E., Stahel, W. A., and Abbt, M.: Log-normal Distributions across the Sciences: Keys and Clues: On the charms of statistics, and how mechanical models resembling gambling machines offer a link to a handy way to characterize log-normal distributions, which can provide deeper insight into variability and probabilitynormal or log-normal: That is the question, AIBS Bulletin, 51, 341-352, 2001.

Lorke, A., Bodmer, P., Noss, C., Alshboul, Z., Koschorreck, M., Somlai-Haase, C., Bastviken, D., Flury, S., McGinnis, D. F., Maeck, A., Müller, D., and Premke, K.: Technical note: drifting versus anchored flux chambers for measuring greenhouse gas emissions from running waters, Biogeosciences, 12, 7013-7024, https://doi.org/10.5194/bg-12-7013-2015, 2015.

Lowe, L., Nathan, R., and Morden, R.: Assessing the impact of farm dams on streamflows, Part II: Regional characterisation, Australasian Journal of Water Resources, 9, 13-26, 2005.

Maeck, A., DelSontro, T., McGinnis, D. F., Fischer, H., Flury, S., Schmidt, M., Fietzek, P., and Lorke, A.: Sediment trapping by dams creates methane emission hot spots, Environ. Sci. Technol., 47, 8130-8137, 2013.

Mantel, S. K., Hughes, D. A., and Muller, N. W.: Ecological impacts of small dams on South African rivers Part 1: drivers of changewater quantity and quality, Water Sa, 36, 351-360, 2010.

Merbach, W., Augustin, J., Kalettka, T., and Jacob, H. J.: Nitrous oxide and methane emissions from riparian areas of ponded depressions of Northeast Germany, J. Appl. Bot. Food Qual., 70, 134-136, 1996.

Musenze, R. S., Grinham, A., Werner, U., Gale, D., Sturm, K., Udy, J., and Yuan, Z.: Assessing the Spatial and Temporal Variability of Diffusive Methane and Nitrous Oxide Emissions from Subtropical Freshwater Reservoirs, Environ. Sci. Technol., 48, 14499-14507, 2014.

Natchimuthu, S., Panneer Selvam, B., and Bastviken, D.: Influence of weather variables on methane and carbon dioxide flux from a shallow pond, Biogeochemistry, 119, 403-413, 2014.

Neil, D. and Mazari, R.: Sediment yield mapping using small dam sedimentation surveys, Southern Tablelands, New South Wales, Catena, 20, 13-25, 1993.

NGERS: Queensland 2015. Australia National Greenhouse Gas Inventory (NGERS), available at: http://ageis.climatechange.gov. au/\# (last access: April 2018), 2015.

Ott, W. R.: Environmental statistics and data analysis, CRC Press, 1994.

Panneer Selvam, B., Natchimuthu, S., Arunachalam, L., and Bastviken, D.: Methane and carbon dioxide emissions from inland waters in India-implications for large scale greenhouse gas balances, Glob. Change Biol., 20, 3397-3407, 2014.

Pekel, J.-F., Cottam, A., Gorelick, N., and Belward, A. S.: Highresolution mapping of global surface water and its long-term changes, Nature, 540, 418-422, 2016. 
QUMLP.: Queensland Land Use Mapping Program (QLUMP) of the Department of Science, Information Techology and Innovation (DSITI), available at: https://www.qld.gov.au/environment/ land/vegetation/mapping/qlump (last access: 5 May 2018), 2018.

Renwick, W., Smith, S., Bartley, J., and Buddemeier, R.: The role of impoundments in the sediment budget of the conterminous United States, Geomorphology, 71, 99-111, 2005.

Rowlings, D., Grace, P., Kiese, R., and Weier, K.: Environmental factors controlling temporal and spatial variability in the soilatmosphere exchange of $\mathrm{CO}_{2}, \mathrm{CH}_{4}$ and $\mathrm{N}_{2} \mathrm{O}$ from an Australian subtropical rainforest, Glob. Change Biol., 18, 726-738, 2012.

Ruxton, G. D., Wilkinson, D. M., and Neuhäuser, M.: Advice on testing the null hypothesis that a sample is drawn from a normal distribution, Anim. Behav., 107, 249-252, 2015.

Scheer, C., Grace, P. R., Rowlings, D. W., Kimber, S., and Van Zwieten, L.: Effect of biochar amendment on the soil-atmosphere exchange of greenhouse gases from an intensive subtropical pasture in northern New South Wales, Australia, Plant Soil, 345, 47-58, 2011.

SKM: Improved assessment of the impact of stock and domestic farm dams in Queensland, Final report to Queensland Government Department of Environment and Resource Management, Brisbane, 2012.

Smith, S., Renwick, W., Bartley, J., and Buddemeier, R.: Distribution and significance of small, artificial water bodies across the United States landscape, Sci. Total Environ., 299, 21-36, 2002.

Sobek, S., DelSontro, T., Wongfun, N., and Wehrli, B.: Extreme organic carbon burial fuels intense methane bubbling in a temperate reservoir, Geophys. Res. Lett., 39, L01401, https://doi.org/10.1029/2011GL050144, 2012.

St. Louis, V. L., Kelly, C. A., Duchemin, É., Rudd, J. W., and Rosenberg, D. M.: Reservoir Surfaces as Sources of Greenhouse Gases to the Atmosphere: A Global Estimate: Reservoirs are sources of greenhouse gases to the atmosphere, and their surface areas have increased to the point where they should be included in global inventories of anthropogenic emissions of greenhouse gases, AIBS Bulletin, 50, 766-775, 2000.
Sturm, K., Yuan, Z., Gibbes, B., Werner, U., and Grinham, A.: Methane and nitrous oxide sources and emissions in a subtropical freshwater reservoir, South East Queensland, Australia, Biogeosciences, 11, 5245-5258, https://doi.org/10.5194/bg-115245-2014, 2014.

Sturm, K., Keller-Lehmann, B., Werner, U., Raj Sharma, K., Grinham, A. R., and Yuan, Z.: Sampling considerations and assessment of Exetainer usage for measuring dissolved and gaseous methane and nitrous oxide in aquatic systems, Limnol. Oceanogr.-Meth., 13, 375-390, 2015.

Swingle, H.: History of warmwater pond culture in the United States, A century of fisheries in North America. American Fisheries Society, Special Publication, 7, 95-105, 1970.

Vacek, J.: Czechoslovakia, in: World Fish Farming: Cultivation and Economics, Springer, 256-271, 1983.

Verpoorter, C., Kutser, T., Seekell, D. A., and Tranvik, L. J.: A global inventory of lakes based on high-resolution satellite imagery, Geophys. Res. Lett., 41, 6396-6402, 2014.

Verstraeten, G. and Poesen, J.: Estimating trap efficiency of small reservoirs and ponds: methods and implications for the assessment of sediment yield, Prog. Phys. Geog., 24, 219-251, 2000.

Verstraeten, G. and Prosser, I. P.: Modelling the impact of land-use change and farm dam construction on hillslope sediment delivery to rivers at the regional scale, Geomorphology, 98, 199-212, 2008.

Zar, J. H.: Biostatistical analysis. 2nd, Prentice Hall USA, 54, 1679, 1984. 